\title{
STUDI KOMPARASI METODE PEMBELAJARAN BAHASA ARAB DAN HASIL BELAJAR BAHASA ARAB DI PONDOK PESANTREN MODERN DAN TRADISIONAL KABUPATEN JAMBI
}

\author{
Afriansyah \\ Fakultas Tarbiyah dan Keguruan UIN STS Jambi \\ e-mail : afri140190@yahoo.com
}

(082175738776)

\begin{abstract}
The aim of this research see the comparison of learning methods and the results of learning Arabic in the modern Al-Hidayah Islamic boarding school in Jambi City and the traditional Sa'adatuddaren Islamic boarding school in Jambi City. The subjects of the study is the head of the modern Al - Hidayah Islamic boarding school in Jambi City and the Jambi City Sa'adatuddaren traditional boarding school, Arabic language teachers in each pesantren and santri of each Islamic boarding school. Data collection technique is a method used by researcher to find data with using a type of qualitative research. Due to the method of learning Arabic in the modern Al-Hidayah Islamic boarding school in the city of Jambi and the traditional Sa'adatuddaren Islamic boarding school in the city of Jambi has a difference and the learning objectives of each pesantren are different. The results of learning Arabic between the modern Al-Hidayah Islamic boarding school in the city of Jambi and the traditional Sa'adatuddaren Islamic boarding school in the city of Jambi there are also clear differences. This is evidenced by the santri of modern Islamic boarding schools in more modern Al - Hidayah Jambi City more able to communicate with Arabic and santri in the traditional Sa'adatuddaren Islamic boarding school in Jambi City more able to read and translate it, when opening books using Arabic santri will be able to directly read and translate it
\end{abstract}

Keywords: earning methods, learning outcomes, Arabic

\section{ABSTRAK:}

Penelitian ini bertujuan untuk melihat perbandinagn metode pembelajaran dan hasil belajar bahasa arab di pondok pesantren modern Al - Hidayah Kota Jambi dan pondok pesantren tradisional Sa'adatuddaren Kota Jambi. Dalam penelitian ini yang menjadi subjek penelitian adalah kepala 
pondok pesantren modern Al - Hidayah Kota Jambi dan pondok pesantren tradisional Sa'adatuddaren Kota Jambi, guru bahasa arab di tiap pesantren dan santri dari masing-masing peantren. Teknik pengumpulan data merupakan cara yang digunakan peneliti untuk mendapatkan data dalam suatu penelitian dan dalam penelitian ini peneliti memilih jenis penelitian kualitatif. Dalam metode pembelajaran bahasa arab di pondok pesantren modern Al - Hidayah Kota Jambi dan pondok pesantren tradisional Sa'adatuddaren Kota Jambi memiliki perbedaan. Hal ini karena tujuan pembelajaran dari masing-masing pesantren berbeda. untuk hasil pembelajaran bahasa arab antara pondok pesantren modern Al - Hidayah Kota Jambi dan pondok pesantren tradisional Sa'adatuddaren Kota Jambi juga terdapat perbedaan yang jelas. Hal ini dibuktikan dengan santri dari pondok pesantren modern lebih modern Al - Hidayah Kota Jambi lebih mampu berkomunikasi dengan bahasa arab dan santri di pondok pesantren tradisional Sa'adatuddaren Kota Jambi lebih mampu membaca dan menerjemahkannya, ketika membuka kitab yang menggunakan bahasa arab santri akan mampu langsung membaca dan menterjemahkannya.

Kata kunci: metode pembelajaran, hasil belajar,bahasa arab.

\section{A. PENDAHULUAN}

Pesantren menurut pengertian dasarnya adalah tempat belajar para santri. Sebagai lembaga pendidikan Islam, pesantren dari sudut historis kultural dapat dikatakan sebagai "training centre" yang otomatis menjadi pusat budaya Islam, yang disahkan atau dilembagakan oleh masyarakat, setidaknya oleh masyarakat Islam sendiri yang secara de facto tidak dapat diabaikan oleh pemerintah. Dari segi historis, pesantren tidak .hanya identik dengan makna keislaman, tetapi juga mengandung makna keaslian Indonesia (Nurcholish Madjid, 1997 : 25). Perbedaan selera Kyai dalam memilih model pembelajaran antara pesantren modern dan pesantren salaf telah menjadikan kedua pihak duduk berseberangan, sehingga masing-masing menggunakan kurikulum yang berbeda dan strategi pembelajaran yang berbeda pula. Dari perbedaan perbedaan itulah yang melahirkan santri santri yang kemampuannya berbeda pula selaras dengan model pesantren dimana santri tersebut belajar.

Memasuki dunia pesantren, pembelajaran bahasa Arab merupakan pembelajaran yang wajib ada di dalamnya. Dalam pembelajaran bahasa Arab siswa diharapkan memiliki keterampilan berbahasa yaitu istimā', kalām, qirā'ah, dan kitābah. Bahasa Arab sebagai bahasa agama mempunyai pengertian bahwa pemahaman terhadap ajaran-ajaran agama secara benar merupakan suatu keharusan bagi para pemeluknya.Tidaklah mungkin bagi seorang muslim untuk dapat melaksanakan kewajiban-kewajiban agama secara benar selama ia tidak memiliki pengetahuan yang benar terhadap ajaran agamanya (Islam), sedangkan ajaran-ajaran islam terkandung di dalam al-Qur'an dan al-Sunnah yang keduanya menggunakan bahasa Arab. 
Sehingga dengan demikian bahasa Arab menjadi kunci bagi pemahaman ajaran agama secara benar (Dhofier, 1985).

Meskipun pesantren salafi dan modern sama-sama memiliki porsi dalam mendalami agama islam baik dari segi pelajaran aqidah, fiqh, dan mempelajari bahasa arab mulai dari kaidah penulisan bahasa arab, dan cara berkomunikasi bahasa arab, akan tetapi metode dan hasil pembelajaran yang jauh berbeda. Pesantren modern pada umumnya telah melakukan perubahan pada metode pengajarannya, perubahan pada kurikulumnya, dan perubahan pada sistem evaluasinya. Perubahan pada metode pembelajaran yang pada mulanya populer menggunakan metodik-didaktif dalam bentuk sorogan, bandongan halaqah, dan hafalan (Amiruddin, 2008 : 27).

Hasil belajar siswa pada hakikatnya adalah perubahan tingkah laku yang telah terjadi melalui proses pembelajaran. Perubahan tingkah laku tersebut berupa kemampuan-kemapuan siswa setelah aktifitas belajar yang menjadi hasil perolehan belajar. Dengan demikian hasil belajar adalah perubahan yang terjadi pada individu setelah mengalami pembelajaran. Hasil belajar memiliki kapasitas berupa pengetahuan, kebiasaan, keterampilan sikap dan cita-cita. Adanya perubahan mental dan perubahan jasmani dan memiliki dampak pengajaran dan pengiring. Hasil belajar siswa sangat dipengaruhi oleh kualitas pembelajaran yang dilaksanakan sekolah. Salah satu hal yang menentukan kualitas pembelajaran adalah penggunaan model pembelajaran yang tepat dengan materi yang diajarkan (Dimyati dan Mudjiono, 2002 : 9).

Penelitian terdahulu tentang pengajaran bahasa arab oleh Ahmad Sholihuddin di pesantren Lirboyo kediri dan al-Amien Sumenep didapatkan bahwa di pondok pesantren Lirboyo pola pembelajaran serta kitab-kitab yang digunakan merupakan kitab-kitab lama atau kitab-kitab agama yang ditulis oleh para ulama zaman abad pertengahan dan kitab-kitab itu dikenal dengan istilah kitab kuning. Sementara di pondok pesantren al-amien sumenep sudah menganut sistem klasikal, terdapat sistem evaluasi serta terdapat masa belajar yang akan berakhir yakni apabila santri dapat diwisuda.

Dari hasil observasi dan wawancara yang peneliti lakukan mengenai pembelajaran bahasa arab di pondok pesantren al-hidayah dan pondok pesantren Sa'adatuddaren, ada beberapa hal yang peneliti temui, peneliti menangkap informasi dari nara sumber yang diwawancarai, mereka yang berada di pondok pesantren al-hidayah mengatakan santri diwajibkan untuk dapat menggunakan bahasa arab sebagai alat komunikasi sesama santri dalam melakukan segala kegiatan sehari-hari hal ini terbukti dengan apa yang peneliti temui dilapangan bahwa santri di pondok pesantren al-hidayah aktif berkomunikasi dengan menggunakan bahasa arab. sedangkan 
di pondok pesantren Sa'adatuddaren bahasa arab lebih digunakan santri untuk menunjang memahami pelajaran karena kitab yang digunakan rata-rata menggunakan bahasa arab.

Berdasarkan hasil observasi dan wawancara yang peneliti lakukan, disimpulkan bahwa terdapat perbedaan metode pembelajaran bahasa arab di masing-masing pesantren. Terdapat perbedaan corak yang terlihat seperti aktifitas pembelajaran bahasa arab dan hasil pembelajaran bahasa arab. Oleh karena itu peneliti ingin menggali lebih jauh mengenai keunggulan metode yang diterapkan masing-masing pesantren dan bagaimana hasil pembalajaran yang telah diterapkan oleh pesantren tersebut.

Berdasarkan uraian latar belakang masalah di atas, maka rumusan masalah yang akan diangkat dalam penelitian ini adalah sebagai berikut: bagaimana metode pembelajaran bahasa arab dan hasil pembelajaran bahasa arab di pondok pesantren al-hidayah (modern) dan pondok pesantren Sa'adatuddaren (salafi)?

\section{B. METODE PENELITIAN}

Permasalahan yang akan dikaji oleh peneliti merupakan masalah yang bersifat sosial dan dinamis. Oleh karena itu, peneliti memilih menggunakan metode penelitian kualitatif untuk menentukan cara mencari, mengumpulkan, mengolah dan menganalisis data hasil penelitian tersebut. Penelitian kualitatif ini dapat digunakan untuk memahami interaksi sosial, misalnya dengan wawancara mendalam sehingga akan ditemukan pola-pola yang jelas.

\section{SUBJEK PENELITIAN}

Subjek penelitian adalah subjek yang dituju untuk diteliti oleh peneliti. Objek penelitian adalah obyek yang dijadikan penelitian atau yang menjadi titik perhatian suatu penelitian. Dalam penelitian ini yang menjadi subjek penelitian adalah kepala pondok pesantren modern AlHidayah Kota Jambi dan pondok pesantren tradisional Sa'adatuddaren Kota Jambi, guru bahasa arab di tiap pesantren dan santri dari masing-masing peantren.

\section{METODE PENGUMPULAN DATA}

Teknik pengumpulan data merupakan cara yang digunakan peneliti untuk mendapatkan data dalam suatu penelitian. Pada penelitian kali ini peneliti memilih jenis penelitian kualitatif maka data yang diperoleh haruslah mendalam, jelas dan spesifik. Pengumpulan data dapat diperoleh dari hasil observasi, wawancara, dokumentasi, dan gabungan/triangulasi. Pada penelitian ini peneliti menggunakan teknik pengumpulan data dengan cara observasi, dokumentasi, dan wawancara (Sugiyono, 2009:225). 


\section{Observasi}

Observasi adalah pengamatan yang dilakukan dengan sengaja dan sistematis terhadap aktivitas individu atau obyek lain yang diselidiki. Adapun jenis-jenis observasi tersebut diantaranya yaitu observasi terstruktur, observasi tak terstruktur, observasi partisipan, dan observasi nonpartisipan (Kusuma, 1987:25).

Dalam penelitian ini, sesuai dengan objek penelitian maka, peneliti memilih observasi partisipan. Observasi partisipan yaitu suatu teknik pengamatan dimana peneliti ikut ambil bagian dalam kegiatan yang dilakukan oleh objek yang diselidiki. Observasi ini dilakukan dengan mengamati dan mencatat langsung terhadap objek penelitian, yaitu dengan mengamati proses pembelajaran bahasa arab di pondok pesantren tradisional dan pondok pesantren modern.

Sehingga peneliti dapat menentukan informan yang akan diteliti dan juga untuk mengetahui jabatan, tugas/kegiatan, alamat, nomor telepon dari calon informan sehingga mudah untuk mendapatkan informasi untuk kepentingan penelitian.

\section{Wawancara}

Dalam teknik pengumpulan menggunakan wawancara hampir sama dengan kuesioner. Wawancara itu sendiri dibagi menjadi 3 kelompok yaitu wawancara terstruktur, wawancara semi-terstruktur, dan wawancara mendalam (in-depth interview).

Namun disini peneliti memilih melakukan wawancara mendalam, ini bertujuan untuk mengumpulkan informasi yang kompleks, yang sebagian besar berisi pendapat, sikap, dan pengalaman pribadi (Sulistyo-Basuki 2006:173).

Untuk menghindari kehilangan informasi, maka peneliti meminta ijin kepada informan untuk menggunakan alat perekam. Sebelum dilangsungkan wawancara mendalam, peneliti menjelaskan atau memberikan sekilas gambaran dan latar belakang secara ringkas dan jelas mengenai topik penelitian.

Peneliti harus memperhatikan cara-cara yang benar dalam melakukan wawancara, diantaranya adalah sebagai berikut:

a. Pewawancara hendaknya menghindari kata yang memiliki arti ganda, taksa, atau pun yang bersifat ambiguitas. 
b. Pewawancara menghindari pertanyaan panjang yang mengandung banyak pertanyaan khusus. Pertanyaan yang panjang hendaknya dipecah menjadi beberapa pertanyaan baru.

c. Pewawancara hendaknya mengajukan pertanyaan yang konkrit dengan acuan waktu dan tempat yang jelas.

d. Pewawancara seyogyanya mengajukan pertanyaan dalam rangka pengalaman konkrit si responden.

e. Pewawancara sebaiknya menyebutkan semua alternatif yang ada atau sama sekali tidak menyebutkan alternatif.

f. Dalam wawancara mengenai hal yang dapat membuat responden marah ,malu atau canggung, gunakan kata atau kalimat yang dapat memperhalus.

\section{Studi Pustaka}

Yaitu Teknik pengumpulan data yang dilakukan dengan mempelajari buku-buku referensi, laporan-laporan, majalah-majalah, jurnal-jurnal dan media lainnya yang berkaitan dengan obyek penelitian.

\section{Dokumentasi}

Dokumen merupakan catatan peristiwa yang sudah berlalu. Dokumen yang digunakan peneliti disini berupa foto, gambar, serta data-data mengenai pondok pesantren tradisional dan pondok pesantren modern. Hasil penelitian dari observasi dan wawancara akan semakin sah dan dapat dipercaya apabila didukung oleh foto-foto (Sugiyono, 2009:240).

\section{E. ANALISIS DATA}

Analisis data kualitatif menurut sebagaimana, adalah upaya yang dilakukan dengan jalan bekerja dengan data, mengorganisasikan data, memilah- milahnya menjadi satuan yang dapat dikelola, mensintesiskannya, mencari dan menemukan pola, menemukan apa yang penting dan apa yang dipelajari, dan memutuskan apa yang dapat diceriterakan kepada orang lain (Bognan \& Biklen, 1982) dalam Moleong , 2007:248).

Berdasarkan definisi di atas dapat disimpulkan bahwa langkah awal dari analisis data adalah mengumpulkan data yang ada, menyusun secara sistematis, kemudian mempresentasikan hasil penelitiannya kepada orang lain. 
Tahapan analisis data kualitatif adalah sebagai berikut:

a. Membaca/mempelajari data, menandai kata-kata kunci dan gagasan yang ada dalam data,

b. Mempelajari kata-kata kunci itu, berupaya menemukan tema-tema yang berasal dari data.

c. Menuliskan 'model' yang ditemukan.

d. Koding yang telah dilakukan.

Analisis data dimulai dengan melakukan wawancara mendalam dengan informan kunci, yaitu seseorang yang benar-benar memahami dan mengetahui situasi obyek penelitian. Setelah melakukan wawancara, analisis data dimulai dengan membuat transkrip hasil wawancara, dengan cara memutar kembali rekaman hasil wawancara, mendengarkan dengan seksama, kemudian menuliskan kata-kata yang didengar sesuai dengan apa yang ada direkaman tersebut.

Setelah peneliti menulis hasil wawancara tersebut kedalam transkrip, selanjutnya peneliti harus membaca secara cermat untuk kemudian dilakukan reduksi data. Peneliti membuat reduksi data dengan cara membuat abstraksi, yaitu mengambil dan mencatat informasi-informasi yang bermanfaat sesuai dengan konteks penelitian atau mengabaikan kata-kata yang tidak perlu sehingga didapatkan inti kalimatnya saja, tetapi bahasanya sesuai dengan bahasa informan.

Abstraksi yang sudah dibuat dalam bentuk satuan-satuan yang kemudian dikelompokkan dengan berdasarkan taksonomi dari domain penelitian. Analisis Domain adalah memperoleh gambaran yang umum dan menyeluruh dari obyek/ penelitian atau situasi sosial. Peneliti memperoleh domain ini dengan cara melakukan pertanyaan grand dan minitour. Sementara itu, domain sangat penting bagi peneliti, karena sebagai pijakan untuk penelitian selanjutnya. Mengenai analisis taksonomi yaitu dengan memilih domain kemudian dijabarkan menjadi lebih terinci, sehingga dapat diketahui struktur internalnya (Sugiyono, 2009:255).

\section{F. PEMBAHASAN}

\section{Metode pembelajaran di pondok pesantren modern Al-Hidayah Kota Jambi}

Metode yang digunakan yakni metode langsung (diprektekkan secara langsung). Khusus untuk pemebelajaran bahasa arab di pesantren modern Al-Hidayah Kota Jambi lebih banyak didapatkan diluar kelas (muhadasah dan mufradat), dalam hal ini pembelajaran bahasa arab 
didapat dari kakak kelas (pengasuh). Pemberian kosa kata bahasa arab untuk dihafalkan berbeda-beda tiap tingkatannya, ada yang setiap pagi mendapatkan pemberian kosa kata bahasa arab dan keesokan harinya kosa kata yang sudah dihafalkan di setorkan kembali, namun ada juga yang dalam 1 minggu mendapatkan 3 kali pembagian kosa kata (senin, rabu, jumat) dan hari sabtu wajib menyetorkan hafalan. Santri juga diwajibkan menggunakan bahasa arab ketika didalam lingkungan pesantren, baik itu didalam kelas ataupun diluar kelas (asrama). Dari kelas 1 mts pembelajaran bahasa arab di pesantren modern menggunakan buku (didalam buku ada gambar dan ada bahasa arabnya). Selain guru dan senior pembelajaran bahasa arab juga didapat dari bagian penanggung jawab bahasa (metode muhadasah). Minat santri dalam mempelajari bahasa arab sangat tinggi karena bahasa arab digunakan untuk berinteraksi dan komunikasi ketika didalam dan diluar kelas. Hal lain yang memotivasi santri mempelajari bahasa arab karena para santri diberikan informasi mengenai banyaknya beasiswa untuk alumni pesantren dengan syarat penguasaan bahasa arab.

\section{Metode pembelajaran bahasa arab di pondok pesantren tradisional Sa'adatuddaren}

\section{Kabupaten Jambi}

Metode pembelajaran bahasa arab yang digunakan di pondok pesantren tradisional Sa'adatuddaren Kota Jambi tidak terfokus hanya dari satu metode, ada beberapa macam metode yang digunakan seperti hafalan, diskusi dan ceramah. Santri juga diminta untuk membuat karangan bahasa arab (insya) dan percakapan bahasa arab (hiwar). Kemudian tujuan menggunakan metode seperti yang telah disebutkan agar santri mudah memahami mata pelajaran lain seperti tafsir hadist dan lain sebagainya. Untuk faktor pendukung pembalajaran bahasa arab Santri di pondok diwajibkan membawa kamus bahasa arab dan menghafalkannya setiap hari. Selain itu santri juga diwajibkan latihan berbicara bahasa arab dan ada hari-hari yang diwajibkan menggunakan bahasa arab. Metode pembelajaran bahasa arab yang digunakan dengan menulis, menghafal, dan menyimak (setoran) kosa kata bahasa arab 4 minggu sekali. Keunggulan dari metode ini para santri bisa memahami dan menguasai bahasa arab dengan cepat. Minat santri dalam mempelajari bahasa arab tergolong tinggi .

Di pesantren tradisional Sa'adatuddaren Kota Jambi santri tidak diwajibkan berkomunikasi dengan bahasa arab. namun lebih ditekankan pada penulisan dan pembacaan bahasa arab. penulisan bahasa arab dibantu dengan mata pelajaran yang lain (imlaq). Untuk pembacaan bahasa arab dibantu dengan mata pelajaran (nahu sorof). Pembelajaran tidak hanya di ajarkan di dalam kelas namun ada bagian penggerak bahasa yang membantu mengajarkan bahasa arab (mencatat kosa kata 1 kali selama 1 bulan). 


\section{Hasil pembelajaran bahasa arab di pondok pesantren modern Al-Hidayah Kota Jambi}

Santri dari pondok pesantren modern Al-Hidayah Kota Jambi mampu berkomunikasi dengan bahasa arab. Dengan sistem yang telah diterapkan jika masih ditemukan ada santri yang tidak mampu menguasai bahasa arab berarti kembali ke individu masing-masing, entah motivasi belajar yang kurang atau tingkat intelegensi dari anak yang kurang mampu untuk mengikuti. Hasil dari metode pembelajaran yang dirasakan santri, banyak mufradat yang terlaksana dan cara berkomunikasi bahasa arab tidak kaku lagi. Hal lain yang memotivasi santri mempelajari. Hasil pembelajaran bahasa arab di pondok pesantren modern jika untuk berkomunikasi dengan bahasa arab sangat baik karena dari observasi dilapangan hampir semua santri berkomunikasi dengan bahasa arab, akan tetapi tidak semua santri mampu menulis dan menterjemahkan bahasa arab yang sesuai dengan aturannya.

\section{Hasil pembelajaran bahasa arab di pondok pesantren tradisional Sa'adatuddaren} Kota Jambi

Santri dari pondok pesantren tradisional Sa'adatuddaren Kota Jambi sangat memahami mata pelajaran yang menggunakan bahasa arab sebagai alat untuk mempelajarinya, seperti tafsir hadist dan lain sebagainya. Jika dilihat hasil belajar bahasa arab di pondok peantren tradisional bisa dikatakan $50 \%$ berhasil, $30 \%$ mengerti, dan $20 \%$ bisa berbahasa arab. Di pesantren tradisional santri tidak diwajibkan berkomunikasi dengan bahasa arab, namun lebih ditekankan pada penulisan dan pembacaan bahasa arab. penulisan bahasa arab dibantu dengan mata pelajaran imlaq. Untuk pembacaan bahasa arab dibantu dengan mata pelajaran nahu sorof. Untuk kemampuan santri dalam komunikasi bahasa arab hanya sebatas mampu mengerti ketika orang berbicara bahasa arab namun untuk menjawab kurang mampu. Kelebihan dari santri di pondok pesantren tradisional terlihat ketika membuka kitab yang menggunakan bahasa arab akan mampu langsung membaca dan menterjemahkannya. Didalam pondok pesantren tradisional untuk komunikasi dalam bahasa arab tidak menjadi kewajiban, sehingga hal ini mengakibatkan santri hanya mampu mengerti ketika orang berbicara bahasa arab namun untuk untuk menjawab. 


\section{G. KESIMPULAN DAN SARAN}

\section{Kesimpulan}

Dari metode pembelajaran dan hasil belajar bahasa arab pada pondok pesantren modern Al-Hidayah Kota Jambi dan pondok pesantren tradisional Sa'adatuddaren Kota Jambi dapat disimpulkan sebagai berikut:

Dalam metode pembelajaran bahasa arab di pondok pesantren modern Al-Hidayah Kota Jambi dan pondok pesantren tradisional Sa'adatuddaren Kota Jambi memiliki perbedaan. Hal ini karena tujuan pembelajaran dari masing-masing pesantren berbeda. Untuk pesantren modern AlHidayah Kota Jambi metode yang digunakan yakni metode langsung (diprektekkan secara langsung). Khusus untuk pemebelajaran bahasa arab di pesantren modern Al-Hidayah Kota Jambi lebih banyak didapatkan diluar kelas (muhadasah dan mufradat), dalam hal ini pembelajaran bahasa arab didapat dari kakak kelas (pengasuh). Metode pembelajaran bahasa arab yang digunakan di pondok pesantren tradisional Sa'adatuddaren Kota jambi tidak terfokus hanya dari satu metode, ada beberapa macam metode yang digunakan seperti hafalan, diskusi dan ceramah. Santri juga diminta untuk membuat karangan bahasa arab (insya) dan percakapan bahasa arab (hiwar). Selain itu di pondok pesantren modern Al-Hidayah Kota Jambi Santri diwajibkan menggunakan bahasa arab ketika didalam lingkungan pesantren, baik itu didalam kelas ataupun diluar kelas (asrama) dan hal ini tidak terjadi pondok pesantren tradisional Sa'adatuddaren Kota jambi, karena di pondok pesantren tradisional Sa'adatuddaren Kota Jambi santri juga diwajibkan latihan berbicara bahasa arab namun tidak diwajibkan untuk setiap hari berkomunikasi dengan bahasa arab, ada hari-hari yang diwajibkan menggunakan bahasa arab. Bahasa arab di pondok pesantren tradisional Sa'adatuddaren Kota Jambi lebih ditekankan pada penulisan dan pembacaan bahasa arab. penulisan bahasa arab dibantu dengan mata pelajaran imlaq kemudian untuk pembacaan bahasa arab dibantu dengan mata pelajaran nahu sorof. Sehingga dapat disimpulkan bahasa arab di pondok pesantren tradisional lebih banyak digunakan sebagai alat untuk mempermudah memahami dan mendalami pelajaran yang ada di pondok pesantren.

2. untuk hasil pembelajaran bahasa arab antara pondok pesantren modern Al-Hidayah Kota Jambi dan pondok pesantren tradisional Sa'adatuddaren Kota Jambi juga terdapat perbedaan yang jelas. Hal ini dibuktikan dengan santri dari pondok pesantren modern AlHidayah Kota Jambi lebih mampu berkomunikasi dengan bahasa arab. Hasil dari metode pembelajaran yang dirasakan santri juga menunjukkan banyak mufradat yang terlaksana dan cara berkomunikasi bahasa arab tidak kaku lagi. Akan tetapi tidak semua santri dari pondok 
pesantren modern mampu menulis dan menterjemahkan bahasa arab yang sesuai dengan aturannya. Hal ini berbanding terbalik dengan santri di pondok pesantren tradisional Sa'adatuddaren Kota Jambi yang mana hasil belajar bahasa arab di pondok peantren tradisional Sa'adatuddaren Kota Jambi bisa dikatakan 50\% berhasil, 30\% mengerti, dan 20\% bisa berbahasa arab. Hal ini terlihat dari kemampuan santri di pondok pesantren tradisional Sa'adatuddaren Kota Jambi ketika membuka kitab yang menggunakan bahasa arab akan mampu langsung membaca dan menterjemahkannya. Didalam pondok pesantren tradisional Sa'adatuddaren Kota Jambi untuk komunikasi dalam bahasa arab tidak menjadi kewajiban, sehingga hal ini mengakibatkan santri hanya mampu mengerti ketika orang berbicara bahasa arab namun untuk untuk menjawab

\section{Saran}

Pada pondok pesantren modern Al-Hidayah Kota Jambi dan pondok pesantren tradisional Sa'adatuddaren Kota Jambi diperlukan perubahan dalam metode pembelajaran bahasa arab. Sehingga santri yang ada di pondok pesantren modern Al-Hidayah Kota Jambi dan tradisional Sa'adatuddaren Kota jambi memiliki kemampuan bahasa arab yang sempurna, yakni mampu berkomunikasi dengan bahasa arab dengan aturan yang benar, mampu membaca tulisan arab dan mampu menterjemahkan bahasa arab dengan baik.

\section{DAFTAR PUSTAKA}

Dimyati dan Mudjiono. 2002. Belajar dan Pembelajaran. Jakarta: Rineka Cipta dan Depdikbud.

Dhofier, Z. (1985). Tradisi Pesantren: Studi Tentang Pandangan Hidup Kyai, Jakarta: LP3ES

Kusuma, S.T. 1987. Psiko Diagnostik. Yogyakarta : SGPLB Negeri Yogyakarta

Madjid, Nurcholish. 1997. Bilik-Bilik Pesantren. Jakarta: Dian Rakyat. Moleong, Lexy J. (2007) Metodologi Penelitian Kualitatif, Penerbit PT Remaja Rosdakarya Offset, Bandung

Nahrawi, Amiruddin, Pembaharuan Pendidikan Pesantren, Yogyakarta: Gama Media, 2008.

Sugiyono, 2009, Metode Penelitian Kuantitatif, Kualitatif dan R\&D, Bandung : Alfabeta. 
Sulistyo-Basuki. 2006. Metode Penelitian. Jakarta: Wedatama Widya Sastra dan Fakultas Ilmu Pengetahuan Budaya Universitas Indonesia 


\title{
DAFTAR ISI
}

\author{
Artikel \\ Adi Nur Rohman \\ Internalisasi Nilai- nilai Islam dalam Praksis Demokrasi \\ di Indonesia \\ hal. 86
}

Sufyati HS

Konstelasi Ekonomi Islam: Peluang dan Tantangan di Era Globalisasi

hal. 99

\section{Lufaefi}

Menusantarakan Al- Qur'an: Mengembalikan Kegemilangan

Budaya Kerukunan Antar Umat Beragama

hal. 120

\section{Afriansyah}

Studi Komparasi Metode Pembelajaran Bahasa Arab dan Hasil Belajar Bahasa Ara di Pondok Pesantren Modern dan Tradisional di Kabupaten Jambi

hal. 135

\section{HIMMAH}

\section{Diterbitkan oleh}

Pusat Pengajian Islam Universitas Nasional JIn. Sawo Mania No. 61 Pejaten, Pasar Minggu,

Jakarta Selatan 12520

Telp. (021) 7806700 Ext. 139

Email: ppi.civitas.unas@gmail.com /

ppi.unas@ac.id

http://www.ppi.unas.ac.id

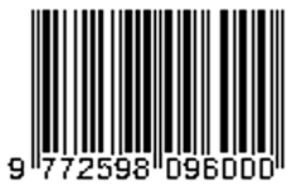

